\title{
Draft genome sequence of strain HIMB100, a cultured representative of the SAR116 clade of marine Alphaproteobacteria
}

Jana Grote ${ }^{1,2}$, Cansu Bayindirli ${ }^{1,3}$, Kristin Bergauer ${ }^{1,4}$, Paula Carpintero de Moraes ${ }^{1,5}$, Huan Chen $^{1,6}$, Lindsay D'Ambrosio ${ }^{1,7}$, Bethanie Edwards ${ }^{1,8}$, Beatriz Fernández-Gómez ${ }^{1,9}$, Mariam Hamisi $^{1,10}$, Ramiro Logares ${ }^{1,9}$, Dan Nguyen ${ }^{1,11}$, Yoshimi M. Rii ${ }^{1,12}$, Emily Saeck ${ }^{1,13}$, Charles Schutte $^{1,14}$, Brittany Widner ${ }^{1,15}$, Matthew J. Church ${ }^{1,12}$,Grieg F. Steward ${ }^{1,12}$, David M. Karl ${ }^{1,12}$, Edward F. DeLong ${ }^{1,16}$, John M. Eppley ${ }^{16}$, Stephan C. Schuster ${ }^{17}$, Nikos C. Kyrpides ${ }^{18}$, and Michael S. Rappé ${ }^{1,2 *}$

${ }^{1}$ Center for Microbial Oceanography: Research and Education, University of Hawaii, Honolulu, Hawaii, USA

${ }^{2}$ Hawaii Institute of Marine Biology, SOEST, University of Hawaii, Kaneohe, Hawaii, USA

3 Plymouth Marine Laboratory, University of East Anglia, Norwich, UK

${ }^{4}$ Department of Marine Biology, University of Vienna, Vienna, Austria

${ }^{5}$ Instituto Oceanografico, Universidade de Sao Paulo, Sao Paulo, Brazil

${ }^{6}$ Environmental Sciences Institute, Florida A\&M University, Tallahassee, Florida, USA

${ }^{7}$ Department of Marine Sciences, University of North Carolina, Chapel Hill, North Carolina, USA

${ }^{8}$ Scripps Institution of Oceanography, University of California, San Diego, La Jolla, California, USA

${ }^{9}$ Departament de Biologia Marina i Oceanografia, Institut de Cièncias del Mar, CMIMA, CSIC, Barcelona, Spain

${ }^{10}$ School of Natural Sciences and Mathematics, The University of Dodoma, Dodoma, Tanzania

11 Département de Sciences Biologiques, Universitéde Montréal, Montréal, Canada

${ }^{12}$ Department of Oceanography, SOEST, University of Hawaii, Honolulu, Hawaii, USA

${ }^{13}$ Australian Rivers Institute, Griffith University, Queensland, Australia

${ }^{14}$ Department of Marine Sciences, University of Georgia, Athens, Georgia, USA

${ }^{15}$ Department of Ocean, Earth and Atmospheric Sciences, Old Dominion University, Norfolk, Virginia, USA

${ }^{16}$ Department of Civil and Environmental Engineering, Massachusetts Institute of Technology, Cambridge, Massachusetts, USA

${ }^{17}$ Center for Comparative Genomics and Bioinformatics, Pennsylvania State University, University Park, Pennsylvania, USA

${ }^{18}$ Department of Energy Joint Genome Institute, Walnut Creek, California, USA

*Corresponding author: Michael S. Rappé (rappe@hawaii.edu)

Keywords: marine bacterioplankton, genome, proteorhodopsin, SAR116, Rhodospirillaceae

Strain HIMB100 is a planktonic marine bacterium in the class Alphaproteobacteria. This strain is of interest because it is one of the first known isolates from a globally ubiquitous clade of marine bacteria known as SAR116 within the family Rhodospirillaceae. Here we describe preliminary features of the organism, together with the draft genome sequence and annotation. This is the second genome sequence of a member of the SAR116 clade. The 2,458,945 bp genome contains 2,334 protein-coding and 42 RNA genes.

\section{Introduction}

HIMB100 is a taxonomically uncharacterized marine bacterial strain isolated from surface seawater collected off the coast of Oahu, Hawaii in the subtropical Pacific Ocean [1]. It is of significant interest because it belongs to a 16S rRNA gene clade of marine Alphaproteobacteria known as SAR116, which was first described by Mullins et al. in 1995 [2] and has since been found to be widespread in the global surface ocean based on cultivation-independent surveys of marine bacterioplankton [3-9]. The first cultured strain of this clade was isolated from surface waters of the Pacific Ocean off the coast of Oregon, USA, in 2007 [10]. In 2010, the genome sequence of Candidatus 
Puniceispirillum marinum IMCC1322, a cultivated member of the SAR116 clade isolated from the East Sea in the Western Pacific Ocean (Sea of Japan), was reported [11]. Here we present a preliminary set of features for strain HIMB100 (Table $1)$, together with a description of the complete genomic sequencing and annotation, as well as a preliminary comparative analysis with the complete genome of Candidatus P. marinum IMCC1322.

\section{Classification and features}

Strain HIMB100 was isolated by a highthroughput, dilution-to-extinction approach [20] from seawater collected off the coast of Hawaii, USA, in the subtropical North Pacific Ocean, and bore an identical $16 \mathrm{~S}$ rRNA gene sequence to three other isolates obtained from the same study [1]. All four strains were isolated in seawater sterilized by tangential flow filtration and amended with low concentrations of inorganic nitrogen and phosphorus $\left(1.0 \mu \mathrm{M} \mathrm{NH}{ }_{4} \mathrm{Cl}\right.$,

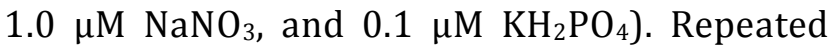
attempts to cultivate the isolates on solidified culture media or in artificial seawater media failed. In addition, preliminary attempts have failed to identify amendments to the seawaterbased culture medium that would increase the abundance of cells in culture above ca. $1 \times 10^{6}$ cells $\mathrm{ml}^{-1}$.

Phylogenetic analyses based on 16S rRNA gene sequence comparisons revealed strain HIMB100 to be closely related to a large number of environmental gene clones obtained almost exclusively from seawater. For example, alignment of HIMB100 against the Silva release 104 reference database $(512,037$ high quality bacterial $16 \mathrm{~S}$ rRNA sequences $>1200$ base pairs in length, released October 2010) revealed 554 entries that belong to the same phylogenetic lineage within the Alphaproteobacteria. Of these, only one originated from a cultivated isolate (Candidatus $\mathrm{P}$. marinum IMCC1322), and all 554 entries derived from either seawater or the marine environment. The 16S rRNA gene sequence from Oregon coast strain HTCC8037 was $98.0 \%$ similar to that of strain HIMB100, but it does not appear in the Silva reference database because it is a partial sequence of 884 nucleotides in length [10]. In phylogenetic analyses with taxonomically described members of the Alphaproteobacteria, strain HIMB100 and Candidatus P. marinum IMCC1322 (94.1\% similar) formed a monophyletic lineage within the family Rhodospirillaceae (Figure 1). The 16S rRNA gene of strain HIMB100 was most similar to the type strains of Nisaea denitrificans (90.3\%), N. nitritireducens (89.9\%), and Thalassobaculum salexigens (89.3\%), which were all isolated from surface seawater of the northwestern Mediterranean Sea $[25,26], T$. litoreum $(89.5 \%)$, isolated from coastal seawater off of Korea [27], and Oceanibaculum indicum (89.4\%), isolated from a polycyclic aromatic hydrocarbondegrading consortium that was enriched from a deep-seawater sample collected from the Indian Ocean [28].

Cells of strain HIMB100 are long, thin spiralshaped rods $(0.3 \times 1-5 \mu \mathrm{m})$ when in exponential growth (Figure 2). Because it is able to grow in media consisting solely of sterile seawater with added inorganic nitrogen and phosphorus in the light or dark, HIMB100 is presumed to grow chemoheterotrophically by oxidizing compounds in the dissolved organic carbon pool of natural seawater. A summary of other known preliminary features is shown in Table 1.

\section{Chemotaxonomy}

No cellular fatty acids profiles are currently available for strain HIMB100, nor have any been reported for other cultivated members of the SAR116 clade.

\section{Genome sequencing and annotation Genome project history}

Strain HIMB100 was selected for sequencing because of its phylogenetic affiliation with a widespread lineage of marine bacteria that is significantly underrepresented in culture collections. The genome project is deposited in the Genomes OnLine Database (GOLD) as project Gi06671, and the complete genome sequence in GenBank as accession number AFXB00000000 [Table 2]. A summary of the main project information is shown in Table 2. 
Table 1. Classification and general features of strain HIMB100 according to the MIGS recommendations [12]

\begin{tabular}{|c|c|c|c|}
\hline MIGS ID & Property & Term & Evidence code \\
\hline & \multirow{8}{*}{ Current classification } & Domain Bacteria & TAS [13] \\
\hline & & Phylum Proteobacteria & TAS [14] \\
\hline & & Class Alphaproteobacteria & TAS $[15,16]$ \\
\hline & & Order Rhodospirillales & TAS $[17,18]$ \\
\hline & & Family Rhodospirillaceae & TAS $[17,18]$ \\
\hline & & Genus not assigned & \\
\hline & & Species not assigned & \\
\hline & & Type strain HIMB100 & IDA \\
\hline & Gram stain & negative & NAS \\
\hline & Cell shape & spiral-shaped & IDA \\
\hline & Motility & unknown & \\
\hline & Sporulation & non-sporulating & NAS \\
\hline & Temperature range & mesophilic & IDA \\
\hline & Optimum temperature & unknown & \\
\hline & Carbon source & ambient seawater DOC & TAS [1] \\
\hline \multirow[b]{2}{*}{ MIGS-6 } & Energy source & chemoorganoheterotrophic & NAS \\
\hline & Habitat & sea water & \\
\hline MIGS-6.3 & Salinity & $\sim 35.0 \%$ & NAS \\
\hline MIGS-22 & Oxygen & aerobic & NAS \\
\hline MIGS-15 & Biotic relationship & free-living & TAS [1] \\
\hline MIGS-14 & Pathogenicity & none & NAS \\
\hline MIGS-4 & Geographic location & Kaneohe Bay, Hawaii, subtropical Pacific Ocean & TAS [1] \\
\hline MIGS-5 & Sample collection time & 18 May 2005 & TAS [1] \\
\hline MIGS-4.1 & Latitude & 21.44 & TAS [1] \\
\hline MIGS-4.2 & Longitude & -157.78 & TAS [1] \\
\hline MIGS-4.3 & Depth & $\sim 1 \mathrm{~m}$ & TAS [1] \\
\hline
\end{tabular}

Evidence codes - IDA: Inferred from Direct Assay (first time in publication); TAS: Traceable Author Statement (i.e., a direct report exists in the literature); NAS: Non-traceable Author Statement (i.e., not directly observed for the living, isolated sample, but based on a generally accepted property for the species, or anecdotal evidence). These evidence codes are from the Gene Ontology project [19]. If the evidence code is IDA, the property was directly observed by one of the authors or an expert mentioned in the acknowledgements.

\section{Growth conditions and DNA isolation}

Strain HIMB100 was grown at $27^{\circ} \mathrm{C}$ in $50 \mathrm{~L}$ of coastal Hawaii seawater sterilized by tangential flow filtration [1] and supplemented with (final concentration) $10 \mu \mathrm{M} \mathrm{NH}{ }_{4} \mathrm{Cl}, 1.0 \mu \mathrm{M} \mathrm{KH}_{2} \mathrm{PO}_{4}, 1.0 \mu \mathrm{M}$ L-serine, $1.0 \mu \mathrm{M}$ L-methionine, $10 \mathrm{mM} \mathrm{FeCl}_{3}, 0.1 \mu \mathrm{M}$ betaine, $0.001 \%$ (wt/vol) of D-ribose, D-glucose, succinic acid, pyruvic acid, glycerol, and N-acetyl-D-glucosamine, 0.002\% (vol/vol) ethanol, and Va vitamin mix at a $10^{-3}$ dilution [20]. Cells from the liquid culture were collected on a membrane filter, and DNA was isolated from the microbial biomass using a standard phenol/chloroform/isoamyl alcohol extraction protocol. A total of ca. $12 \mu \mathrm{g}$ of DNA was obtained. 


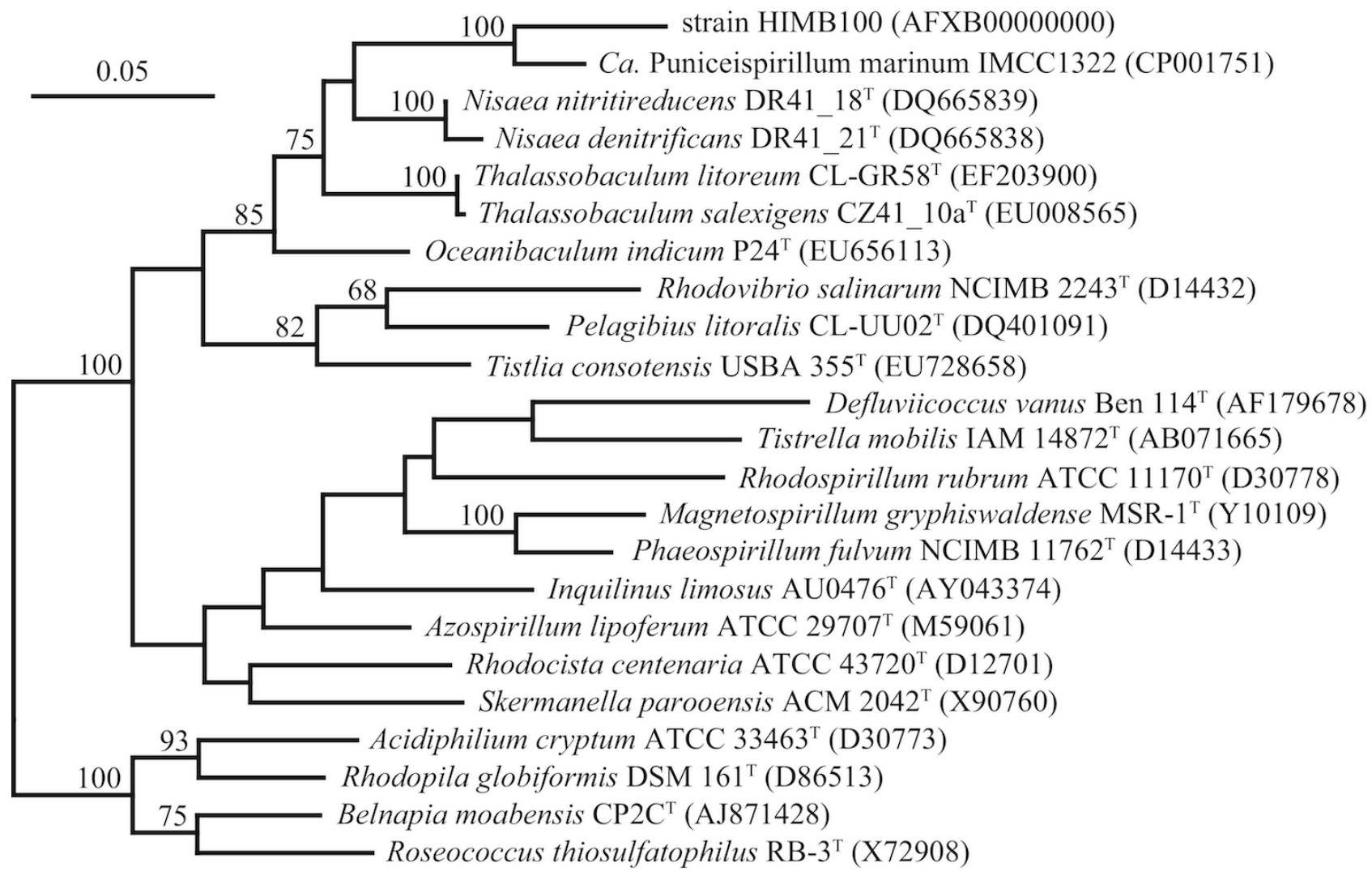

Figure 1. Phylogenetic tree based comparisons between 16S rRNA gene sequences from strain HIMB100, Candidatus Puniceispirillum marinum IMCC1322, and type strains of related species within the family Rhodospirillaceae. Sequence selection and alignment improvements were carried out using the 'All-Species Living Tree' project database [21] and the ARB software package [22]. The tree was inferred from 1,206 alignment positions using the RAxML maximum likelihood method [23]. Support values from 100 bootstrap replicates, determined by RAxML [24], are displayed above branches if larger than $60 \%$. The scale bar indicates substitutions per site.



Figure 2. Scanning electron micrograph of strain HIMB100. Scale bar corresponds to $1 \mu \mathrm{m}$. 
Table 2. Genome sequencing project information

\begin{tabular}{lll}
\hline MIGS ID & Property & Term \\
\hline MIGS-31 & Finishing quality & Finished \\
MIGS-28 & Libraries used & one standard 454 pyrosequence titanium library \\
MIGS-29 & Sequencing platforms & 454 GS FLX Titanium \\
MIGS-31.2 & Fold coverage & $132 \times$ pyrosequence \\
MIGS-30 & Assemblers & Newbler version 2.3 \\
MIGS-32 & Gene calling method & Prodigal 1.4, GenePRIMP \\
& Genbank ID & AFXB00000000 \\
& Genbank Date of Release & November 10, 2011 \\
& GOLD ID & Gi0667 \\
& Database: IMG & 2503113005 \\
& NCBI taxon ID & 281031 \\
MIGS-13 & Source material identifier & HIMB100 \\
& Project relevance & environmental \\
\hline
\end{tabular}

\section{Genome sequencing and assembly}

The genome of strain HIMB100 was sequenced at the Pennsylvania State University Center for Comparative Genomics and Bioinformatics (University Park, PA, USA) using the 454 GS FLX Ti platform of 454 Life Sciences (Branford, CT, USA). The sequencing library was prepared according to the 454 instructions from genomic DNA of strain HIMB100. Sequencing was carried out on a full 454 picotiter plate, yielding 1,342,353 reads with an average length of $415 \mathrm{bp}$, totaling $556 \mathrm{Mbp}$. Pyrosequencing reads were assembled using the Newbler assembler version 2.3, resulting in 10 contigs of 2,458,945 bp. Sequencing provided 132 $\times$ coverage of the genome.

\section{Genome annotation}

Genes were identified using Prodigal [29] as part of the genome annotation pipeline in the Integrated Microbial Genomes Expert Review (IMG-ER) system [30]. The predicted coding sequences were translated and used to search the National Center for Biotechnology Information (NCBI) nonredundant database, UniProt, TIGRFam, Pfam, PRIAM, KEGG, COG, and InterPro databases. The tRNAScanSE tool [31] was used to find tRNA genes, whereas ribosomal RNAs were found by using the tool RNAmmer [32]. Other non-coding RNAs were identified by searching the genome for the Rfam profiles using INFERNAL (v0.81) [33]. Additional gene prediction analysis and manual functional annotation was performed within IMG-ER.

\section{Genome properties}

The genome is $2,458,945 \mathrm{bp}$ long and comprises 10 contigs ranging in size from 30,717 to $1,167490 \mathrm{bp}$, with an overall GC content of 50.48 $\%$ (Table 3 and Figure 3). Of the 2,376 genes predicted, 2,334 were protein coding genes, and 42 were RNAs. Most protein coding genes (82.0\%) were assigned putative functions, while the remaining genes were annotated as hypothetical proteins. The distribution of genes into COG functional categories is presented in Table 4.

\section{Genome comparisons with Candidatus Puniceispirillum marinum IMCC1322}

The genome of one other member of the SAR116 clade, Candidatus P. marinum IMCC1322, was recently sequenced [11]. This genome is 2,753,527 bp in length (295 Kbp longer than HIMB100), arranged in a single chromosome, and possesses a G $+\mathrm{C}$ content similar to that of HIMB100 (48.85\% vs. $50.48 \%$ ). Although the genome of Candidatus $\mathrm{P}$. marinum IMCC1322 is annotated with over 200 more genes than HIMB100 $(2,582$ genes vs. $2,376)$, it only encodes for 51 additional proteincoding genes with predicted function.

The predicted metabolic potentials encoded by the two genomes have many features in common. The genomes of both strains possess a lesion in the Embden-Meyerhoff-Parnas pathway in that they lack the enzyme 6-phosphofructokinase. However, the genomes of both strains possess two 
key enzymes of the Entner-Doudoroff pathway, phosphogluconate dehydratase and 2-keto-3deoxy-phosphogluconate aldolase. The oxidative portion of the pentose phosphate pathway is incomplete in both strains; the genome of HIMB100 lacks a recognizable 6-phosphogluconolactonase, while the genomes of both strains lack a recognizable 6-phosphogluconate dehydrogenase. In addition, several genes of predicted biogeochemical importance are present in both strains, including proteorhodopsin and carotenoid biosynthesis genes, carbon monoxide dehydrogenase, dimethylsulfoniopropionate (DMSP) demethylase, and dimethylsulfoxide (DMSO) reductase. Genes for assimilatory sulfate reduction are incomplete in both genomes, and so it is hypothesized that exogenous reduced sulfur compounds, such as DMSP and DMSO, are likely to fill the requirement of sulfur for cellular growth. The genomes of both strains possess a high affinity inorganic phosphate transport system (pstSCAB), and encode a phosphate regulon sensor (phoU), phosphate starvation-inducible protein $(\mathrm{phoH})$, and the phosphate regulon consisting of the phoB-phoR two-component system. Both genomes encode for $\mathrm{ABC}$ transporters for iron, glycine betaine/proline, zinc, sorbitol/mannitol, amino acids (branchedchain and general L-amino acids), sulfonate/nitrate/taurine and a heme exporter. Thiamine and alpha-glucoside transport systems were only identified within the genome of strain HIMB100, while ribose and putrescine transport systems were only identified within the genome of Candidatus P. marinum IMCC1322. Finally, two operons of potential ecological relevance show different distributions within the two genomes: the genome of strain HIMB100 possesses a sevengene operon encoding all of the subunits and accessory proteins for urease that is completely lacking in the genome of Candidatus P. marinum IMCC1322, while the genome of Candidatus P. marinum IMCC1322 possesses 21 genes for cobalamin biosynthesis that are absent from the genome of strain HIMB100.

Table 3. Genome statistics

\begin{tabular}{lrr}
\hline Attribute & Value & \% $^{\text {of total }}{ }^{\mathbf{a}}$ \\
\hline Genome size (bp) & $2,458,945$ & 100.00 \\
DNA coding region (bp) & $2,260,613$ & 91.91 \\
DNA G+C content (bp) & $1,241,171$ & 50.48 \\
Total genes & 2,376 & 100.00 \\
RNA genes & 42 & 1.77 \\
Protein-coding genes & 2,334 & 98.23 \\
Genes with function prediction & 1,948 & 81.99 \\
Genes assigned to COGs & 1,873 & 78.83 \\
Genes assigned to Pfam domains & 1,957 & 82.37 \\
Genes with signal peptides & 733 & 30.43 \\
Genes with transmembrane helices & 504 & 21.21 \\
\hline
\end{tabular}

a) The total is based on either the size of the genome in base pairs or the total number of protein coding genes in the annotated genome. 


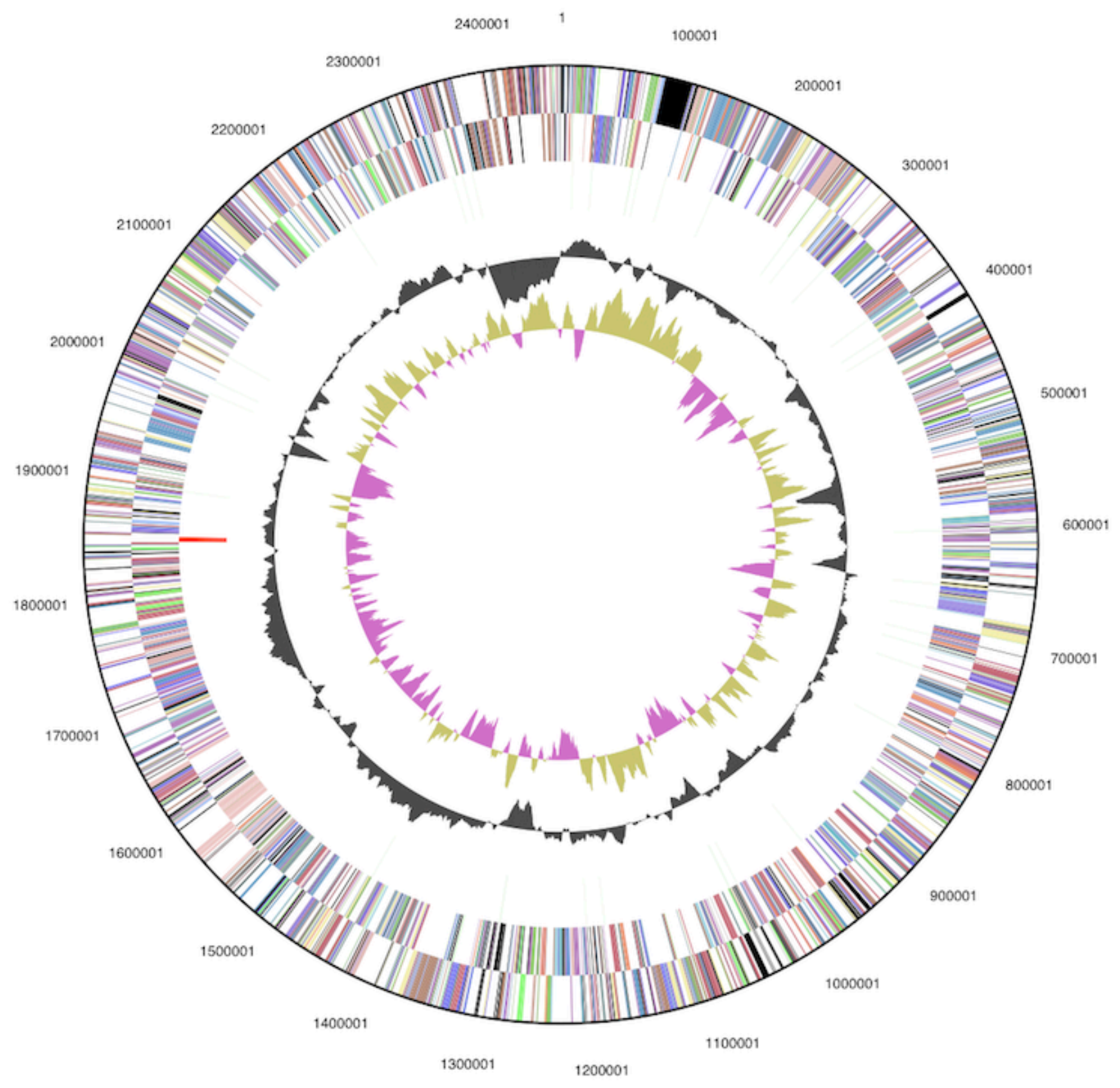

Figure 3. Graphic circular map of the HIMB100 genome. From outside to the center: Genes on forward strand (colored by COG categories), Genes on reverse strand (colored by COG categories), RNA genes (tRNAs green, rRNAs red, other RNAs black), GC content, GC skew. The 10 contigs of the draft genome are ordered randomly. 
Table 4. Number of genes associated with the 25 general COG functional categories

\begin{tabular}{|c|c|c|c|}
\hline Code & Value & $\%$ oge $^{a}$ & Description \\
\hline$J$ & 142 & 6.8 & Translation \\
\hline A & 0 & 0 & RNA processing and modification \\
\hline K & 77 & 3.7 & Transcription \\
\hline $\mathrm{L}$ & 93 & 4.5 & Replication, recombination and repair \\
\hline B & 2 & 0.1 & Chromatin structure and dynamics \\
\hline $\mathrm{D}$ & 20 & 1.0 & Cell cycle control, mitosis and meiosis \\
\hline $\mathrm{Y}$ & 0 & 0 & Nuclear structure \\
\hline V & 16 & 0.8 & Defense mechanisms \\
\hline $\mathrm{T}$ & 41 & 2.0 & Signal transduction mechanisms \\
\hline M & 142 & 6.8 & Cell wall/membrane biogenesis \\
\hline $\mathrm{N}$ & 41 & 2.0 & Cell motility \\
\hline Z & 0 & 0 & Cytoskeleton \\
\hline W & 0 & 0 & Extracellular structures \\
\hline$U$ & 40 & 1.9 & Intracellular trafficking and secretion \\
\hline $\mathrm{O}$ & 89 & 4.3 & Posttranslational modification, protein turnover, chaperones \\
\hline $\mathrm{C}$ & 149 & 7.1 & Energy production and conversion \\
\hline G & 126 & 6.0 & Carbohydrate transport and metabolism \\
\hline $\mathrm{E}$ & 250 & 12.0 & Amino acid transport and metabolism \\
\hline $\mathrm{F}$ & 58 & 2.8 & Nucleotide transport and metabolism \\
\hline $\mathrm{H}$ & 117 & 5.6 & Coenzyme transport and metabolism \\
\hline I & 113 & 5.4 & Lipid transport and metabolism \\
\hline $\mathrm{P}$ & 70 & 3.4 & Inorganic ion transport and metabolism \\
\hline Q & 78 & 3.7 & Secondary metabolites biosynthesis, transport and catabolism \\
\hline $\mathrm{R}$ & 271 & 13.0 & General function prediction only \\
\hline $\mathrm{S}$ & 155 & 7.4 & Function unknown \\
\hline- & 503 & 21.2 & Not in COGs \\
\hline
\end{tabular}

a) The total is based on the total number of protein coding genes in the annotated genome.

\section{Acknowledgements}

We gratefully acknowledge the support of the Gordon and Betty Moore Foundation, which funded sequencing of this genome. Annotation was performed as part of the 2010 Summer Course in Microbial Oceanography (http://cmore.soest.hawaii.edu/summercourse/2010/ index.htm), with support from the Agouron Institute, the Gordon and Betty Moore Foundation, the University of Hawaii at Manoa School of Ocean and Earth Science and Technology (SOEST), and the Center for Microbial Oceanography: Research and Education (C-MORE), a National Science Foundation-funded Science and Technology Center (award No. EF0424599). This is SOEST contribution 8364 and HIMB contribution 1459. 


\section{References}

1. Rappé MS, Brandon ML. Diversity among bacteria from the coastal subtropical Pacific Ocean determined by high-throughput culturing and smallsubunit rRNA gene clone libraries. In review.

2. Mullins TD, Britschgi TB, Krest RL, Giovannoni SJ. Genetic comparisons reveal the same unknown bacterial lineages in Atlantic and Pacific bacterioplankton communities. Limnol Oceanogr 1995; 40:148-158. doi:10.4319/lo.1995.40.1.0148

3. Rappé MS, Kemp PF, Giovannoni SJ. Phylogenetic diversity of marine coastal picoplankton $16 \mathrm{~S}$ rRNA genes cloned from the continental shelf off Cape Hatteras, North Carolina. Limnol Oceanogr 1997; 42:811-826. doi:10.4319/lo.1997.42.5.0811

4. Acinas SG, Antón J, Rodríquez-Valera F. Diversity of free-living and attached bacteria in offshore western Mediterranean waters as depicted by analysis of genes encoding $16 \mathrm{~S}$ rRNA. App/ Environ Microbiol 1999; 65:514-522. PubMed

5. Rappé MS, Vergin K, Giovannoni SJ. Phylogenetic comparisons of a coastal bacterioplankton community with its counterparts in open ocean and freshwater systems. FEMS Microbiol Ecol 2000; 33:219-232. PubMed doi:10.1016/S0168$\underline{6496(00) 00064-7}$

6. Giovannoni SJ, Rappé MS. (2000). Evolution, diversity and molecular ecology of marine prokaryotes. In: Kirchman DL (ed), Microbial Ecology of the Oceans. Wiley and Sons. pp. 47-84.

7. Suzuki MT, Béjà O, Taylor LT, DeLong EF. Phylogenetic analysis of ribosomal RNA operons from uncultivated coastal marine bacterioplankton. Environ Microbiol 2001; 3:323-331. PubMed doi:10.1046/j.1462-2920.2001.00198.x

8. Giovannoni SJ, Stingl U. Molecular diversity and ecology of microbial plankton. Nature 2005; 437:343-348. PubMed doi:10.1038/nature04158

9. DeLong EF, Preston CM, Mincer T, Rich V, Hallam SJ, Frigaard NU, Martinez A, Sullivan MB, Edwards R, Brito BR, et al. Community genomics among stratified microbial assemblages in the ocean's interior. Science 2006; 311:496-503. PubMed doi:10.1126/science. 1120250

10. Stingl U, Tripp HJ, Giovannoni SJ. Improvements of high-throughput culturing yielded novel SAR11 strains and other abundant marine bacteria from the Oregon coast and the Bermuda Atlantic Time
Series study site. ISME J 2007; 1:361-371. PubMed

11. Oh HM, Kwon KK, Kang I, Kang SG, Lee JH, Kim SJ, Cho JC. Complete genome sequence of "Candidatus Puniceispirillum marinum": IMCC1322, a representative of the SAR116 clade in the Alphaproteobacteria. I Bacteriol 2010; 192:3240-3241. PubMed doi:10.1128//B.00347-10

12. Field D, Garrity G, Gray T, Morrison N, Selengut J, Sterk P, Tatusova T, Thomson N, Allen MJ, Angiuoli SV, et al. The minimum information about a genome sequence (MIGS) specification. Nat Biotechnol 2008; 26:541-547. PubMed doi:10.1038/nbt1360

13. Woese CR, Kandler O, Wheelis ML. Towards a natural system of organisms: proposal for the domains Archaea, Bacteria, and Eucarya. Proc Natl Acad Sci USA 1990; 87:4576-4579. PubMed doi:10.1073/pnas.87.12.4576

14. Garrity GM, Bell JA, Lilburn T. Phylum XIV. Proteobacteria phyl. nov. In: Garrity GM, Brenner DJ, Krieg NR, Staley JT (eds), Bergey's Manual of Systematic Bacteriology, Second Edition, Volume 2, Part B, Springer, New York, 2005, p. 1.

15. Validation List No. 107. List of new names and new combinations previously effectively, but not validly, published. Int I Syst Evol Microbiol 2006; 56:1-6. PubMed doi:10.1099/ijs.0.64188-0

16. Garrity GM, Bell JA, Lilburn T. Class I. Alphaproteobacteria class. nov. In: Garrity GM, Brenner DJ, Krieg NR, Staley JT (eds), Bergey's Manual of Systematic Bacteriology, Second Edition, Volume 2, Part C, Springer, New York, 2005, p. 1.

17. Skerman VBD, McGowan V, Sneath PHA. Approved Lists of Bacterial Names. Int / Syst Bacteriol 1980; 30:225-420. doi:10.1099/00207713$\underline{30-1-225}$

18. Pfennig N, Trüper HG. Higher taxa of the phototrophic bacteria. Int J Syst Bacteriol 1971; 21:1718. doi:10.1099/00207713-21-1-17

19. Ashburner M, Ball CA, Blake JA, Botstein D, Butler H, Cherry JM, Davis AP, Dolinski K, Dwight SS, Eppig JT, et al. Gene Ontology: tool for the unification of biology. Nat Genet 2000; 25:2529. PubMed doi:10.1038/75556

20. Rappé MS, Connon SA, Vergin KL, Giovannoni SJ. Cultivation of the ubiquitous SAR11 marine bacterioplankton clade. Nature 2002; 418:630633. PubMed doi:10.1038/nature00917 
21. Yarza P, Richter M, Peplies J, Euzeby J, Amann R, Schleifer KH, Ludwig W, Glöckner FO, RossellóMóra R. The All-Species Living Tree project: a $16 \mathrm{~S}$ rRNA-based phylogenetic tree of all sequenced type strains. Syst App/ Microbiol 2008; 31:241-250. PubMed doi:10.1016/j.syapm.2008.07.001

22. Ludwig W, Strunk O, Westram R, Richter L, Meier H, Kumar Y, Buchner T, Lai S, Steppi G, Jobb W, et al. ARB: a software environment for sequence data. Nucleic Acids Res 2004; 32:1363-1371. PubMed doi:10.1093/nar/gkh293

23. Stamatakis A. RAxML-VI-HPC: maximum likelihood-based phylogenetic analyses with thousands of taxa and mixed models. Bioinformatics 2006; 22:2688-2690. PubMed doi:10.1093/bioinformatics/btl446

24. Stamatakis A, Hoover $P$, Rougemont J. A rapid bootstrap algorithm for the RAxML web-servers. Syst Biol 2008; 57:758-771. PubMed doi:10.1080/10635150802429642

25. Urios L, Michotey $\mathrm{V}$, Intertaglia L, Lesongeur F, Lebaron P. Nisaea denitrificans gen. nov., sp. nov. and Nisaea nitritireducens sp. nov., two novel members of the class Alphaproteobacteria from the Mediterranean Sea. Int J Syst Evol Microbiol 2008; 58:2336-2341. PubMed doi:10.1099/ijs.0.64592-0

26. Urios L, Michotey V, Intertaglia L, Lesongeur F, Lebaron P. Thalassobaculum salexigens sp. nov., a new member of the family Rhodospirillaceae from the NW Mediterranean Sea, and emended description of the genus Thalassobaculum. Int J Syst Evol Microbiol 2010; 60:209-213. PubMed doi:10.1099/ijs.0.011460-0
27. Zhang Gl, Hwang CY, Cho BC. Thalassobaculum litoreum gen. nov., sp. nov., a member of the family Rhodospirillaceae isolated from coastal seawater. Int I Syst Evol Microbiol 2008; 58:479485. PubMed doi:10.1099/ijs.0.65344-0

28. Lai Q, Yuan J, Wu C, Shao Z. Oceanibaculum indicum gen. nov., sp. nov., isolated from deep seawater of the Indian Ocean. Int J Syst Evol Microbiol 2009; 59:1733-1737. PubMed doi:10.1099/ijs.0.004341-0

29. Hyatt D, Chen GL, LoCascio PF, Land ML, Larimer FW, Hauser LJ. Prodigal: prokaryotic gene recognition and translation initiation site identification. BMC Bioinformatics 2010; 11:119.

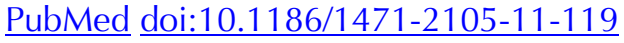

30. Markowitz VM, Ivanova NN, Chen A, Chu K, Kyrpides NC. IMG-ER: a system for microbial genome annotation expert review and curation. Bioinformatics 2009; 25:2271-2278. PubMed doi:10.1093/bioinformatics/btp393

31. Lowe TM, Eddy SR. tRNAscan-SE: a program for improved detection of transfer RNA genes in genomic sequence. Nucleic Acids Res 1997; 25:955-964. PubMed doi:10.1093/nar/25.5.955

32. Lagesen K, Hallin P, Rodland EA, Staerfeldt HH, Rognes T, Ussery DW. RNAmmer: consistent and rapid annotation of ribosomal RNA genes. Nucleic Acids Res 2007; 35:3100-3108. PubMed doi:10.1093/nar/gkm160

33. Griffiths-Jones $S$, Moxon S, Marshall M, Khanna A, Eddy SR, Bateman A. Rfam: annotating noncoding RNAs in complete genomes. Nucleic Acids Res 2004; 33:D121-D124. PubMed doi:10.1093/nar/gki081 